УДК 621.77 .04

М. П. Рудь, к.т.н., доцент,

e-mail: hochspannung77@gmail.com

О. О. Похил, аспірант,

e-mail: olegpokhyl@gmail.com

С. В. Заболотній, д.m.н., доиент,

e-mail: s.zabolotnii@chdtu.edu.ua

А. П. Солтус, д.m.н., професор

Черкаський державний технологічний університет

б-р Шевченка, 460, м. Черкаси, 18006, Україна

\title{
КІНЦЕВОЕЛЕМЕНТНЕ МОДЕЛЮВАННЯ ТЕРМОМЕХАНІЧНОЇ ПОВЕДІНКИ ВИРОБІВ $З$ ПОЛІМЕРНИХ МАТЕРІАЛІВ ПРИ ЇХ ВИГОТОВЛЕННІ МЕТОДОМ ПОШАРОВОГО НАПЛАВЛЕННЯ
}

3D-друк функиіональних деталей має суттєві переваги порівняно з традиційними технологіями завдяки здатності виготовляти деталі зі складними формами без необхідності виготовляти спеціалізовану оснастку. Однак існує ряд геометричних форм об'єктів, отримання яких з допомогою 3D-друку потребує додаткових досліджень. Одними з таких об'єктів є тонкостінні деталі. В роботі побудовано математичну модель теплопровідності проиесу $3 D$-друку тонкостінних виробів з метою визначення оптимальних параметрів технологічного процесу, при яких забезпечуються мінімальні термодеформачії виробу і максимальна адгезія шарів.

Ключові слова: 3D-принтер, FDM, моделювання методом наплавлення, метод скінченних елементів.

Вступ. Технології адитивного виробництва являють собою групу технологій, в яких виготовлення виробу здійснюється за рахунок нарощування матеріалу шар за шаром. Історично адитивне виробництво стало розвитком технологій швидкого прототипування (Rapid Prototyping) і передбачає створення функціональних деталей, готових до використання. Технологія моделювання методом наплавлення Fused Deposition Modeling (FDM) або Fused Filament Fabrication (FFF) на сьогодні $€$ найбільш поширеною та доступною 3 технологій адитивного виробництва [1]. Ця технологія інтенсивно розвивається, постійно розширюючи сферу застосування та перелік доступних матеріалів 3 широким вибором властивостей.

Аналіз проблеми та останніх досліджень. Процес виготовлення виробів методом наплавлення $\epsilon$ багатофакторним. Результатом виконання процесу $\epsilon$ виготовлення виробу, який має відповідати заданим вимогам якості. Фактори, що впливають на властивості виробу, можна розділити на такі, що залежать від конструктивних особливостей $3 \mathrm{D}$-принтера, i технологічні параметри власне 3D-друку. На сьогодні відомі різноманітні різновиди конструкцій 3D-принтерів, які за заявами виробників дозволяють досягати високих показників якості деталей.

FDM 3D-друк функціональних деталей має суттєві переваги порівняно 3 традиційни- ми технологіями завдяки здатності виготовляти деталі зі складними формами без необхідності виготовляти спеціалізовану оснастку, як то ливарні форми, профільні інструменти тощо. Функціональні вироби, виготовлені методом FDM, що мають різноманітне застосування в медицині, автомобілебудуванні та інших важливих галузях, повинні забезпечувати різноманітні вимоги з геометричної точності, механічних властивостей, хімічної стійкості, біосумісності тощо [2-9].

Як нова технологія, яка знаходить все більше практичне застосування, 3D-друк привертає увагу широкого кола науковців та практиків. Значна частина досліджень присвячена вивченню термомеханічної поведінки виробів під час друку та впливу технологічних параметрів 3D-друку на геометричну точність виробів [10-11]. Точність геометричних форм функціональних деталей $є$ важливим фактором, який визначає їх експлуатаційні характеристики.

Серед завдань, які на сьогодні є недостатньо дослідженими, можна виокремити процеси формування тонкостінних деталей методом наплавлення. Виготовлення таких виробів може становити значний інтерес завдяки перевагам 3D-друку, за умови вирішення проблем, викликаних низькою жорсткістю виробу, що може деформуватися в результаті явищ термодеформації, оплавлення кількох нижніх шарів пластику при накладанні нового 
шару, механічного впливу від сопла екструдера, під дією гравітаційних сил тощо [12].

Метою дослідження с побудова математичної моделі теплопровідності процесу 3D-друку тонкостінних виробів та визначення оптимальних параметрів технологічного процесу, при яких забезпечуються мінімальні термодеформації виробу і максимальна адгезія шарів.

\section{Виклад основного матеріалу}

Постановка задачі теплопровідності. Розглянемо пряму задачу теплопровідності. Як видно на рис. 1, модель складається 3 двох частин, а саме: робочого столу зі скла (I) та виробу, який друкується 3 ASA пластику (II). На верхню границю виробу діє теплове джерело від сопла екструдера 3 циліндричним розподілом потужності по перерізу, що рухається вздовж стінок виробу з постійною швидкістю. Також будемо вважати, що всі поверхні моделі знаходяться у контакті з повітрям навколишнього середовища 3 кімнатною температурою $25^{\circ} \mathrm{C}$. Початкові умови задачі також враховують температуру попереднього нагріву робочого стола $100^{\circ} \mathrm{C}$.

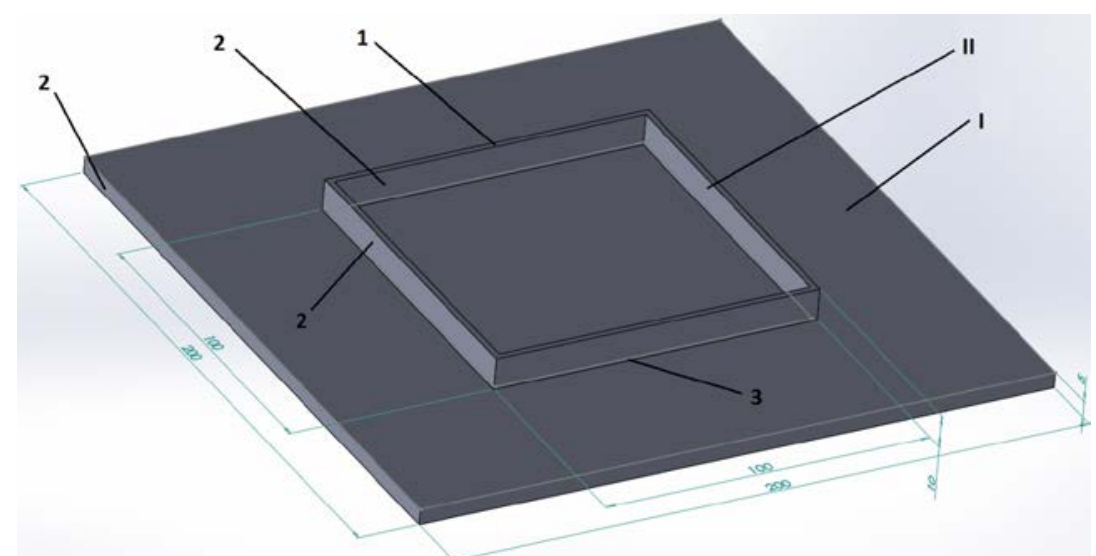

Рис. 1. Схема моделі розрахунку теплопровідності під час 3D-друку

Поверхні зразка обмінюються теплом 3 навколишнім середовищем температури $T_{a m b}$ за рахунок механізмів теплопровідності та конвективного теплообміну.

Розподіл потужності на контакті сопла екструдера та поверхні виробу описується законом $F(x, t)$, який відповідає циліндричному джерелу тепла діаметром 1 мм.

Розподіл температури всередині деталі описується диференційним рівнянням:

$$
\begin{aligned}
& C_{V}(T) \frac{\partial T}{\partial x}+\frac{\partial}{\partial x}\left(-\lambda(T) \frac{\partial T}{\partial x}\right)+ \\
& +\frac{\partial}{\partial y}\left(-\lambda(T) \frac{\partial T}{\partial y}\right)+\frac{\partial}{\partial z}\left(-\lambda(T) \frac{\partial T}{\partial z}\right)=0
\end{aligned}
$$

де $\lambda(T)$ - коефіцієнт теплопровідності, Вт/(м·К); $C_{V}(T)$ - об'ємна теплоємність, Дж/(кг $\mathrm{K})$.

\section{Початкові та граничні умови:}

Як початкова умова береться температура повітря $25^{\circ} \mathrm{C}$ i температура робочого стола (об’єкт I) $100^{\circ} \mathrm{C}$.

Як граничні умови задається тепловий потік на поверхні 1 від сопла екструдера (крайові умови II роду), на поверхні 3, що відпо- відає контакту між нагрівним столом і друкованою деталлю, умова неперервності теплового потоку (крайові умови IV роду), для всіх інших модельованих поверхонь задаються умови конвективного теплообміну (крайові умови II роду).

Розробка цифрової моделі досліджуваного об'скта. Описана вище задача може бути вирішена лише на базі чисельних методів.

Розв’язання цієї задачі здійснимо за допомогою пакета моделювання фізичних процесів COMSOL Multiphysics. Вирішення диференційних рівнянь у цьому пакеті здійснюється методом кінцевих елементів.

Побудова фізичної моделі в COMSOL складається з наступних етапів:

1) Вибір вимірності, фізичної задачі та числового вирішувача. Задано вирішення тривимірної задачі, фізична задача теплопровідності в твердих тілах Heat Transfer in Solids, обрано двокрокове вирішування: перший крок для стаціонарних умов - Stationary, другий для нестаціонарних- Time Dependent.

2) Прорисовка геометрії моделі. Ми будемо проводити розрахунки для випадку початку друку та в процесі друку (коли виріб 
вже частково сформовано на робочому столі). Геометричні розміри відповідають зображе- ним на рис. 1. Вигляд заготовки моделі 3 обраними параметрами показано на рис. 2 .
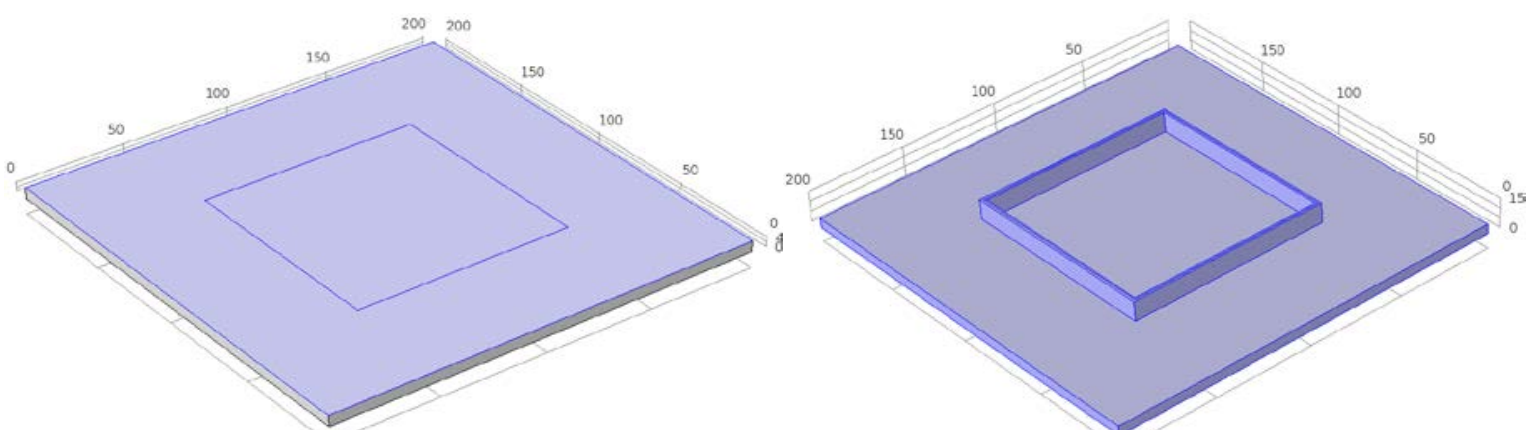

Рис. 2. Побудова геометрії моделі в пакеті COMSOL

3) Встановлення фізичних властивостей об'єкта моделювання та початкових умов задачі. Було обрано з бібліотеки матеріалів віконне скло та ABS пластик. Слід зазначити, що за умовами задачі (1) коефіцієнт теплопровідності $\lambda$ та питома теплоємність $C_{p}$ залежать від температури. В реальному матеріалі ця залежність нелінійна і іï врахування збільшить точність розрахунку.

4) Встановлення граничних умов задачі. Граничні умови задачі встановлені відповідно до постановки задачі теплопровідності.

Початкові умови визначають кімнатну температуру навколишнього середовища.

$$
\left.T(x, y, z)\right|_{t=0}=T_{a m b}=25^{\circ} \mathrm{C} .
$$

\section{Граничні умови:}

Границя 1 (рис. 1): тепловий потік через поверхню (нелінійні крайові умови)

$$
-n \cdot q=P_{l} \cdot f(O, e) \frac{|e \cdot n|}{\|e\|},
$$

де $P_{l}$ - потужність джерела тепла (від дії сопла екструдера), Вт; $e$ - вектор орієнтації напряму джерела тепла; $O$ - координати розташування точки центру джерела тепла.

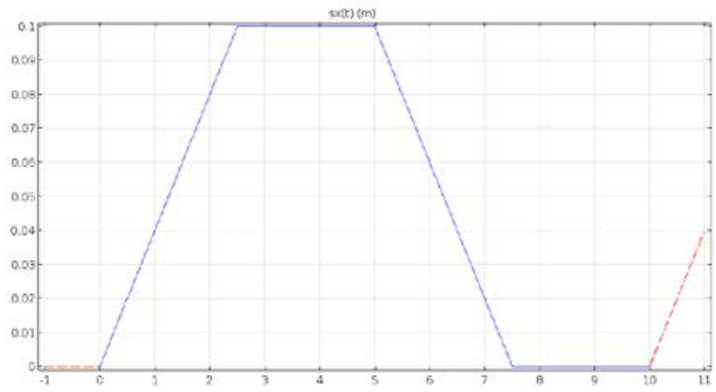

Рис. 3. Функції руху джерела тепла по осях Ох та Оу
Необхідно задати рівняння руху джерела тепла, при якому воно обчислюється по квадратній траєкторії зі швидкістю 2,5 см/с. Для цього задаються функції руху джерела по осях Ох та Оу. Графіки рівняння складаються 3 хвилеподібної трикутної функції $t s(t)$, аналітичної функції $x s t(t)=(t s(t+1.25)+0.05)$ і шматочної функції $s x(x, t)$ та $s y(y, t)$ (табл. 2,3$)$ i представлені на рис. 3.

Таблиця 1

Шматочна функція $s x(x, t)$

\begin{tabular}{|c|c|c|}
\hline Start & End & Function \\
\hline 0 & 2,5 & $x s t(t)$ \\
\hline 2,5 & 5 & 0,1 \\
\hline 5 & 7,5 & $x s t(t)$ \\
\hline 7,5 & 10 & 0 \\
\hline
\end{tabular}

Таблиця 2

Шматочна функція sy(y,t)

\begin{tabular}{|c|c|c|}
\hline Start & End & Function \\
\hline 0 & 2,5 & $x s t(t)$ \\
\hline 2,5 & 5 & 0,1 \\
\hline 5 & 7,5 & $x s t(t)$ \\
\hline 7,5 & 10 & 0 \\
\hline
\end{tabular}

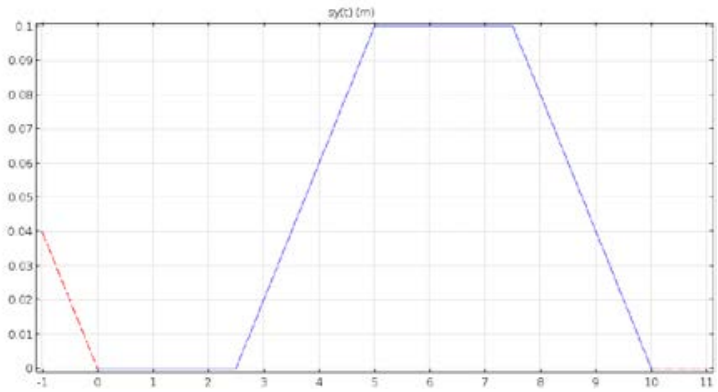


Границя 2: вільний конвективний теплообмін уздовж вертикальної стінки

$$
-n \cdot q=q_{0},
$$

де $q_{0}=h\left(T_{\text {ext }}-T\right)$;

$h$ - коефіцієнт тепловіддачі

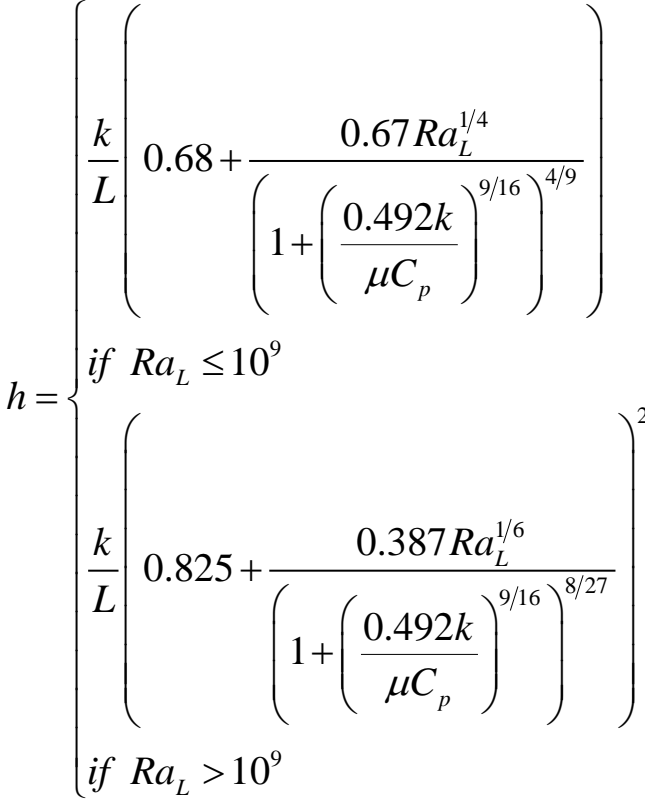

$$
\begin{aligned}
& L \text { - висота стінки; } \\
& R a_{L} \text { - число Релея. }
\end{aligned}
$$

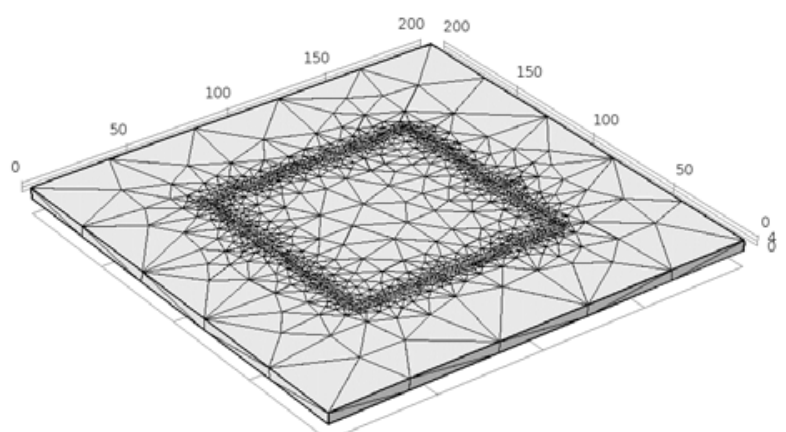

Рис. 4. Зображення моделі в режимі розбиття на кінцеві елементи

Вирішення задачі. Перед запуском вирішення задачі необхідно задати параметри вирішення та обрати один з вирішуючих пристроїв, реалізованих у пакеті COMSOL. Для вирішення першої задачі (початок друку) вирішення проходить в один етап. Враховуючи час проходження сопла по заготовці, обрано часовий діапазон вирішення від 0 до 20 секунд 3 кроком 0,1 секунди, що дозволить провести розрахунок двох проходів сопла по периметру деталі. Для вирішення другої задачі (друк стінки) вирішення відбувається в два етапи. Оскільки нагрів друкованої стінки відбувається знизу від нагрівного стола 3 постій-
Границя 3: умова неперервності теплового потоку

$$
\begin{aligned}
& -n_{1}\left(-\lambda_{1} \frac{\partial T_{1}}{\partial z}\right)-n_{2}\left(-\lambda_{2} \frac{\partial T_{2}}{\partial z}\right)=0 ; \\
& T_{1}(x, z)=T_{2}(x, z) ;(x, z)
\end{aligned}
$$

5) Розбиття об'єкта на кінцеві елементи. Пакет COMSOL дозволяе автоматично розбивати об'єкти на елементи. Обираючи початкові параметри сітки розбиття, користувач може керувати цим процесом відповідно до необхідної точності розрахунку.

Для цієї моделі було обрано такі параметри: кінцеві елементи мають форму трикутників (Lagrange-Quadratic), автоматично будується сітка 3 параметром Extremely Coars (надзвичайно груба), за винятком поверхні друкованого виробу, для якого обрано параметр сітки Coarser (грубіша) та границі, на якій відбувається контакт джерела тепла 3 моделлю (рис. 1), де обрано сітку Extremely Fine (надзвичайно тонка) 3 максимальним розміром кінцевих елементів 0,5 мм (оскільки саме на цій границі можливі найбільші градієнти температури від дії теплового джерела). Результат розбиття об'єкта показано на рис. 4. Сітка складається 311027 та 7394 елементів відповідно.

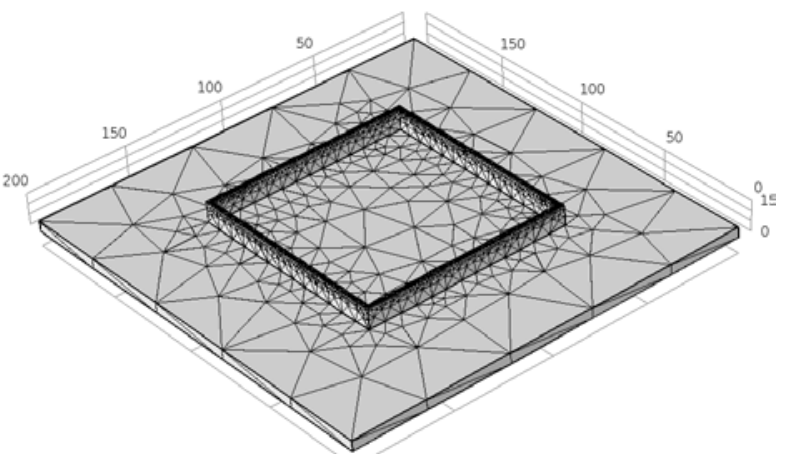

ною температурою і час нагріву значно більший, ніж час проходження соплом одного периметра, цей процес можна вважати стаціонарним. Тому використовуємо вирішувач Stationary. Другий крок вирішення відбувається аналогічно, як для першої задачі. Для дослідження поширення тепла на нижні шари під час друку проведемо розрахунок дев'яти проходів сопла по периметру деталі.

Обробка отриманих даних. В досліджуваному випадку нас цікавить розподіл температури на поверхні об'єкта та на стінках виробу, що друкується. 
Результати розрахунку для початку друку представлені на рис. 5. Розподіл температури на поверхні робочого стола при проходженні сопла екструдера в різні моменти часу зображено на рис. 6. Основним завданням розрахунку цієї моделі є визначення оптимальних параметрів, при яких можна забезпечити фіксацію першого шару на підложці.
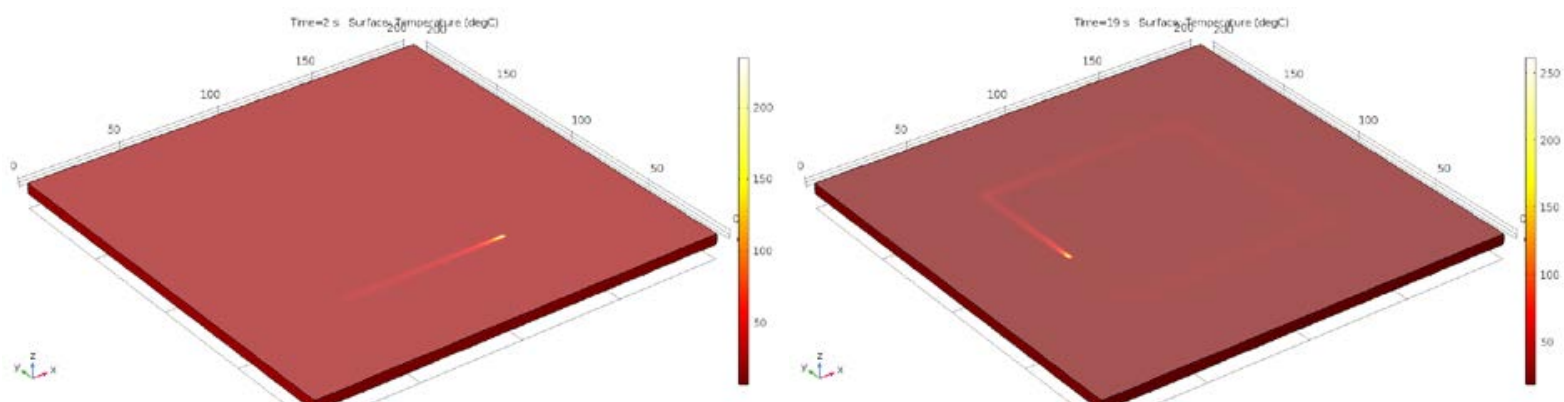

Рис. 5. Розподіл температури на поверхні робочого стола при проходженні сопла екструдера

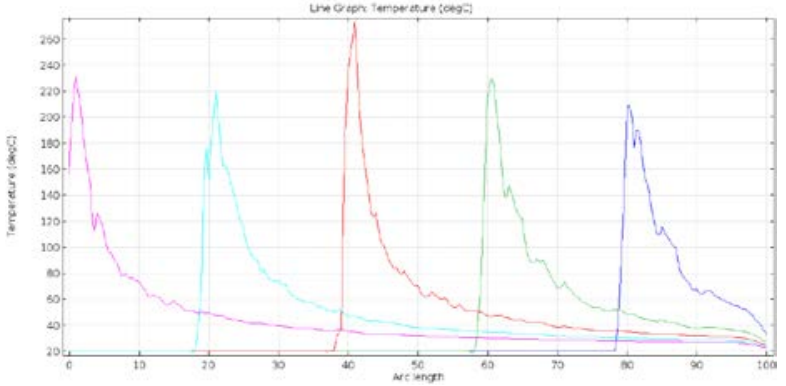

Рис. 6. Розподіл температури на поверхні скляної підложки в різних положеннях сопла екструдера при нанесенні першого шару деталі
На рис. 7-8 показано розраховану температуру в частково надрукованому виробі. Цей розрахунок дозволяє встановити розподіл температури вздовж стінки виробу під час друку, а також зміну температури на попередньо надрукованих шарах виробу. Це дасть змогу визначити оптимальні параметри друку, при яких не відбувається оплавлення нижніх шарів, що може призвести до деформації моделі. Іншим важливим завданням моделювання $\epsilon$ визначення термодеформацій для запобігання деламінації шарів моделі.

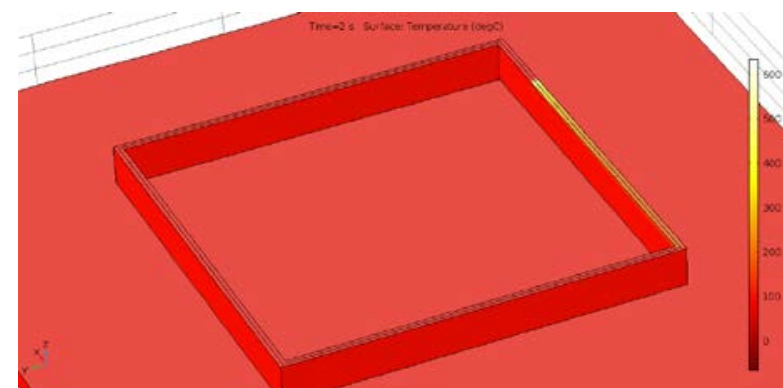

a)

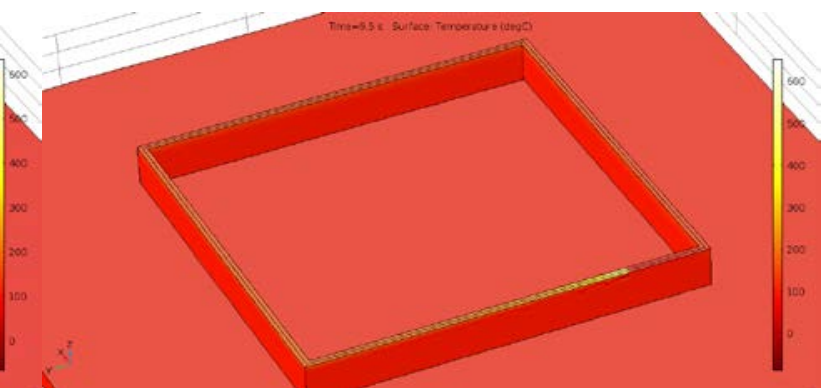

б)

Рис. 7. Розподіл температури на поверхні друкованого виробу при проходженні сопла екструдера (а - перший прохід, б - дев’ятий прохід)

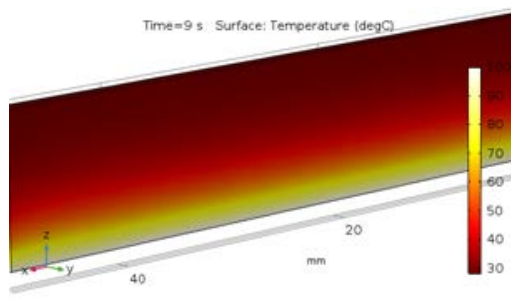

a)

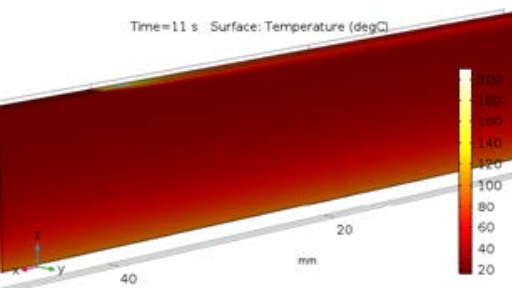

б)

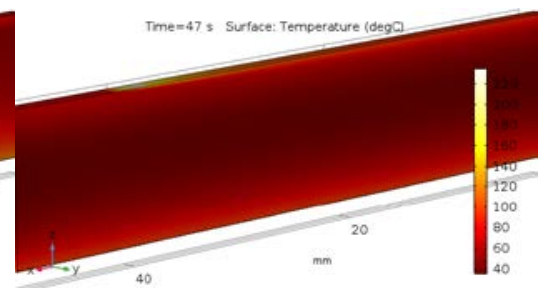

в)

Рис. 8. Розподіл температури на поверхні стінки друкованого виробу при проходженні сопла екструдера

( $а$ - після вирішення стаціонарної задачі, б - перший прохід, в - дев'ятий прохід) 


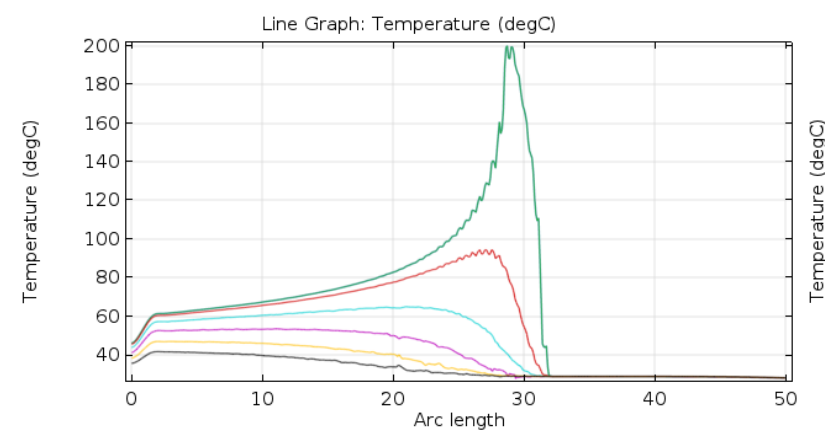

a

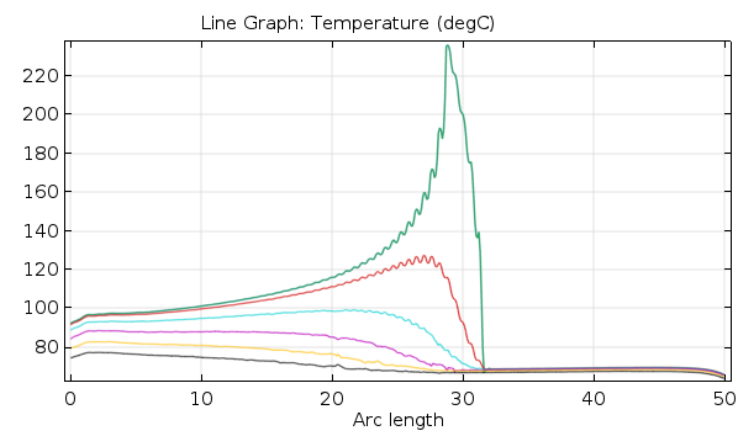

6

Рис. 9. Розподіл температури на поверхні стінки друкованого виробу та в приповерхневих шарах на глибині з кроком 0,1 мм (товщина одиничного шару при друці) при проходженні сопла екструдера (а - перший прохід, б - дев'ятий прохід)

Дослідження розподілу температури на поверхні стінки друкованого виробу та в приповерхневих шарах в моменти проходження сопла (рис. 9) показало, що при обраних режимах друку перший нижній шар може нагріватись до температури $120^{\circ} \mathrm{C}$, а другий шар - до температури $95^{\circ} \mathrm{C}$. Враховуючи, що для ABS пластику температура розм'якшення знаходиться в межах $95-117^{\circ} \mathrm{C}$, можна вважати обрані режими друку оптимальними 3 точи зору геометричних параметрів моделі, тому що вони забезпечують максимальну адгезію нанесених шарів 3 мінімальною деформацією внаслідок оплавлення нижніх шарів.

Також було проведено дослідження зміни температури на поверхні друкованої стінки протягом дев'яти проходів сопла. Як можна побачити на рис. 10, максимальна температура спочатку поступово зростає і після п'яти-шести проходів залишається практично незмінною. Це дозволяє зробити висновок, що, оскільки моделювання не проводиться за весь час друку виробу (що потребувало б дуже великих затрат машинного часу), перші розраховані проходи не цілком адекватно описують термічну поведінку моделі. Для моделювання необхідно обчислювати не менше шести проходів сопла. Це збільшує загальний час розрахунку. Але такий підхід значно ефективніший, ніж розрахунок побудови всієї моделі.

Для друку якісної моделі тонкостінного виробу, як раніше зазначалось, важливе значення має контроль термодеформацій. На рис. 11 представлено розподіл температури по глибині стінки друкованого виробу. Як видно з розрахунку, при висоті стінки 10 мм перепад температури досягає близько $55^{\circ} \mathrm{C}$. Графік для дев'ятого проходу сопла майже симетричний, що дозволяє зробити висновок про правильно обрану температуру попереднього нагріву стола, яка мінімізує термодеформаційні навантаження. Водночас для великих деталей такі зміни температури можуть призвести до деламінації виробу. Тому в таких випадках слід використовувати попередній нагрів повітря в камері принтера.

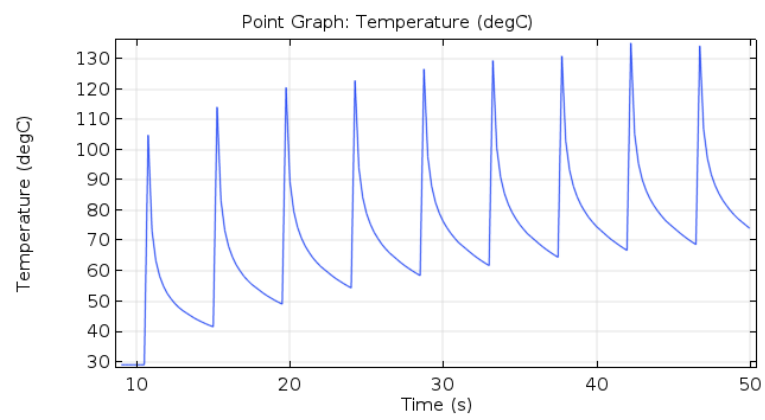

Рис. 10. Зміна температури на поверхні стінки друкованого виробу за дев'ять проходів сопла

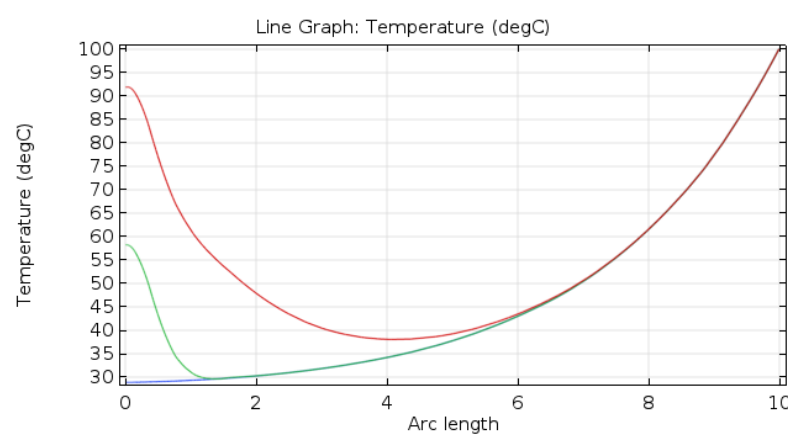

Рис. 11. Розподіл температури по глибині стінки друкованого виробу після вирішення стаціонарної задачі, після першого проходу та після дев'ятого проходу

Висновки. Було проведено кінцевоелементне моделювання поширення тепла в процесі 3D-друку тонкостінного виробу методом пошарового наплавлення. В результаті 
досліджень було запропоновано оптимальні параметри технологічного процесу 3D-друку для оптимізації термомеханічної поведінки виробів, при яких забезпечуються мінімальні термодеформації виробу і максимальна адгезія шарів для тонкостінних виробів простої прямокутної форми. Показано необхідність коригування параметрів залежно від довжини периметра виробу.

Розроблена математична модель в подальшому може використовуватись для коригування технологічних параметрів 3D-друку виробів складної форми зі змінним периметром по висоті деталі.

\section{Список літератури}

1. Turner B. N., Strong R., Gold S. A. A review of melt extrusion additive manufacturing processes: I. Process design and modeling. Rapid Prototyping Journal. 2014. Vol. 20, No. 3. P. 192-204.

2. Yin J., Lu C., Fu J., Huang Y., Zheng Y. Interfacial bonding during multi-material fused deposition modeling (FDM) process due to inter-molecular diffusion. Materials \& Design. 2018. Vol. 150. P. 104-112.

3. Zhang J., Wang X. Z., Yu W. W., Deng Y. H. Numerical investigation of the influence of process conditions on the temperature variation in fused deposition modeling. Materials and Design. 2017. Vol. 130. P. 59-68.

4. Costa S. F., Duarte F. M., Covas J. A. Estimation of filament temperature and adhesion development in fused deposition techniques. Journal of Materials Processing Technology. 2017. Vol. 245. P. 167-179.

5. Malekipour E., Attoye S., El-Mounayri H. Investigation of layer based thermal behavior in fused deposition modeling process by infrared thermography. Procedia Manufacturing. 2018. Vol. 26. P. 1014-1022.

6. Wang J., Xie H., Weng Z., Senthil T., Wu L. A novel approach to improve mechanical properties of parts fabricated by fused deposition modeling. Materials \& Design. 2016. Vol. 105. P. 152-159.

7. Montero M., Roundy S., Odell D. Material characterization of fused deposition modeling (FDM) ABS by designed experiments. Proceedings of Rapid Prototyping \& Manufacturing Conference. 2001. P. 1-21.
8. Dizon J. R. C., Espera A. H., Chen Q., Advincula R. C. Mechanical characterization of 3D-printed polymers. Additive Manufacturing. 2018. Vol. 20. P. 44-67.

9. Ahn S. H., Montero M., Odell D., Roundy S., Wright P. K. Anisotropic material properties of fused deposition modeling ABS. Rapid Prototyping Journal. 2002. Vol. 8, No. 4. p. 248-257.

10. Armillotta A., Bellotti M., Cavallaro M. Warpage of FDM parts: experimental tests and analytic model. Robotics and ComputerIntegrated Manufacturing. 2018. Vol. 50, May. P. 140-152.

11. Sun Q., Rizvi G. M., Bellehumeur C. T., $\mathrm{Gu}$ P. Effect of processing conditions on the bonding quality of FDM polymer filaments. Rapid Prototyping Journal. 2008. Vol. 14, No. 2. P. 72-80.

12. Du J., Wei Z., Wang X., Wang J., Chen Z. An improved fused deposition modeling process for forming large-size thin-walled parts. Journal of Materials Processing Technology. 2016. Vol. 234. P. 332-341.

\section{References}

1. Turner, B. N., Strong, R., Gold, S. A. (2014) A review of melt extrusion additive manufacturing processes: I. Process design and modeling. Rapid Prototyping Journal, vol. 20, No. 3, pp. 192-204.

2. Yin, J., Lu, C., Fu, J., Huang, Y., Zheng, Y. (2018) Interfacial bonding during multimaterial fused deposition modeling (FDM) process due to inter-molecular diffusion. Materials \& Design, vol. 150, pp. 104-112.

3. Zhang, J., Wang, X. Z., Yu, W. W., Deng, Y. H. (2017) Numerical investigation of the influence of process conditions on the temperature variation in fused deposition modeling. Materials and Design, vol. 130, pp. 59-68.

4. Costa, S. F., Duarte, F. M., Covas, J. A. (2017) Estimation of filament temperature and adhesion development in fused deposition techniques. Journal of Materials Processing Technology, vol. 245, pp. 167-179.

5. Malekipour, E., Attoye, S., El-Mounayri, H. (2018) Investigation of layer based thermal behavior in fused deposition modeling process by infrared thermography. Procedia Manufacturing, vol. 26, pp. 1014-1022. 
6. Wang, J., Xie, H., Weng, Z., Senthil, T., Wu, L. (2016) A novel approach to improve mechanical properties of parts fabricated by fused deposition modeling. Materials \& Design, vol. 105, pp. 152-159.

7. Montero, M., Roundy, S., Odell, D. (2001) Material characterization of fused deposition modeling (FDM) ABS by designed experiments. Proceedings of Rapid Prototyping \& Manufacturing Conference, pp. 1-21.

8. Dizon, J. R. C., Espera, A. H., Chen, Q., Advincula R. C. (2018) Mechanical characterization of 3D-printed polymers. Additive Manufacturing, vol. 20, pp. 44-67.

9. Ahn, S. H., Montero, M., Odell, D., Roundy, S., Wright P. K. (2002) Anisotropic material properties of fused deposition model- ing ABS. Rapid Prototyping Journal, vol. 8, No. 4, pp. 248-257.

10. Armillotta, A., Bellotti, M., Cavallaro, M. (2018) Warpage of FDM parts: experimental tests and analytic model, Robotics and Computer-Integrated Manufacturing, vol. 50, May, pp. 140-152.

11. Sun, Q., Rizvi, G. M., Bellehumeur, C. T., Gu P. (2008) Effect of processing conditions on the bonding quality of FDM polymer filaments. Rapid Prototyping Journal, vol. 14, No. 2, pp. 72-80.

12. Du, J., Wei, Z., Wang, X., Wang, J., Chen, Z. (2016) An improved fused deposition modeling process for forming large-size thin-walled parts. Journal of Materials Processing Technology, vol. 234, pp. 332-341.

M. P. Rud, Ph.D., associate professor, e-mail: hochspannung77@gmail.com

O. O. Pokhyl, postgraduate student, e-mail: olegpokhyl@gmail.com

S. V. Zabolotnii, Dr.Tech.Sc., associate professor, e-mail: s.zabolotnii@chdtu.edu.ua

A. P. Soltus, Dr.Tech.Sc., associate professor

Cherkasy State Technological University

Shevchenko blvd, 460, Cherkasy, 18006, Ukraine

\section{FINITE ELEMENT MODELING OF THERMOMECHANICAL BEHAVIOR OF POLYMERIC MATERIALS PRODUCTS AT THEIR MANUFACTURE BY THE METHOD OF LAYER-BY-LAYER BUILDING-UP}

The 3D printing of functional components has significant advantages over conventional technologies due to the ability to fabricate parts with complex shapes without the need to produce specialized equipment. However, there are a number of geometric forms of objects, which require extra research, using $3 D$ printing. Thin-walled parts are one of these objects. In the paper the mathematical model of thermal conductivity of the process of $3 D$ printing of thin-walled products is constructed in order to determine the optimal parameters of technological process, which provide the minimum thermal deformation of the product and the maximum adhesion of layers.

Keywords: 3D printer, FDM, modeling by building-up method, finite element method.

Стаття надійшла до редакиії 03.09.2018.

Статтю представляє С. В. Заболотній, д.т.н., доцент. 